\title{
English Literary Portrait of the Arabs
}

\author{
Fahd Mohammed Taleb Saeed Al-Olaqi \\ Department of English, Faculty of Science \& Arts - Khulais, King Abdulaziz University, Kingdom of Saudi Arabia \\ Email: fahdmtm@yahoo.co.uk
}

\begin{abstract}
This article highlights the progress of the images of Arabs in English literature. Europe owes a debt of gratitude to Arabia and the East. In early history, Arabia is the birthplace of all the major heavenly religions. In later periods, Oriental scholarship played a significant role in promoting crosscultural transmission in the West. The English medieval literary depiction distorted the image of Arabs. Some literary portraits of the Arabs have depicted Arabs as tyrant caliphs, weak kings, lustful princes, medieval Saracens, mysterious travellers, filthy Bedouins, and immoral women. Modern English Orientalists work to explore the Arabian characters with reference to Islam. Islamist Arabs are represented as a threat to the West. Authentic secular literary outlook can greatly help the spread of the Arabic culture in the West.
\end{abstract}

Index Terms-Arabia Felix, the Magi, frankincense, Saracens, Sheba, and Arabian Phoenix, 9/11

\section{INTRODUCTION}

The Arabs are one of the most ancient races of mankind. They have, of all others, perhaps, best preserved their national independence and their distinctive character and manners. The Arabs are now of two descendants; the majority are from Qahtan, originally Sabians, and the others are of the lineal descendants of Ishmael, son of the Messenger of Allah, Abraham and Hagar (Florian, 1857, p.22). The Bible tells us that three Wise Men prostrated themselves and paid homage to Jesus. They were originally from Yemen, a place where Jews enjoyed majority during that time and up to the appearance of the Prophet Muhammad in Mecca, a time in which all of them became Muslims. The Three Yemeni kings or wise men are known as the Magi who came from the East, guided by a star, and brought gifts of gold, frankincense, and Myrrh for the baby Jesus. The image of the Magi is clearly shown as Arabian in the Western art and during Christmas. Biblical Magi were received as Arabian Kings. The expression, "the kings of Arabia and Saba shall bring gifts," is the epiphany of the lord to the gentiles. ${ }^{1}$

With the advent of Islam in $632 \mathrm{AD}$, the history of the world changed. As Arabs spread Islam in less than one hundred years after the death of the Prophet Muhammad, the Arab Empire and civilization demonstrated positive reception for many other religions and cultures. The presence of scientist Arabs is remarkable in the history of science. The influence of Islam extended from the banks of Indus to the Pyrenees. The light of Arabian learning is indivisible from the influence of Islam. The scientific inventions of Lord Bacon and of Roger Bacon were based on the Arabian masters. Besides this gratitude was a proportional broadmindedness. ${ }^{2}$ Positive examples of Muslim-Christian cooperation can also be found elsewhere. In 1076, Sultan al-Nasir of Bejaya wrote an appeal to Pope Gregory VII for the ordination of a home priest to take care of the Christian inhabitants in the Islamic Empire. The Christian Emperor Charlemagne and the Abbasid Caliph Harun Al-Rashid made agreements for Christians to travel to the Holy Land. The Arab Christians established hostels to serve Christian pilgrims along the way to Jerusalem (Hitti, 1964, p. 315). Before the eleventh century, the poetical romances of the Spanish Saracens appear to have kindled a spirit which soon crossed the interjacent kingdoms, to strike root and flourish in the South of France (Forster, 1829, p. 318). In the twelfth century, Toledo was a significant hub of learning for scholars from all over Europe who came to work with native speakers of Arabic. The Arabian civilization showed openness to the advantages to cultural, civilizational, scholastic, and religious cooperation. The present article approaches the images of the Arabs in English literature.

\section{The Medieval PortrayAl OF ARABS}

In Webster's 1913 dictionary, the word 'Saracen,' (Latin: Saracenus) is a noun and means sharqi in Arabic, Oriental, or Eastern. In Arabic, Sharaqa means the risinge sun. In the Middle Ages, 'Saracen' is the common term among Christians in Europe for an Arab or a Muslim (mistakenly called Mohammedan), hostile to the crusaders. According to the Encyclopaedia Britannica, the term 'Saracen' means any Arab, Turk, or Muslim. Earlier, in the Roman world, there had been references to Saracens (Greek: Sarakenoi) by late classical authors in the first three centuries AD, the term being then applied to an Arab tribe, living in the Sinai Peninsula. In the succeeding centuries, the use of the term by

\footnotetext{
${ }^{1}$ Biblical Magi From Wikipedia, the free encyclopaedia

${ }^{2}$ For discussions of relations between Muslims, Christians and Jews in early Islam see Jane I. Smith, .Islam and Christendom, in The Oxford History of Islam ch8, John L. Esposito, ed., (New York: Oxford University press, 1999), Bernard Lewis. The Arabs in History, revised edition. New York: Harper \& Row Publishers, 1966, 58 ff, and Brian Beedham. Muslims and Westerners: The Reformation of Cultures. London: The Eleni Nakou Foundation, 1997, 3ff.
} 
Christians was extended to denote Arab tribes in general; and after the establishment of the caliphate, the Byzantines referred to all Muslim subjects of the caliph as Saracens. Through the Byzantines and the crusades, the name spread into Western Europe, where it was long in general use and survived until modern times. ${ }^{3}$ Norman Daniel, a British critic, explains that academicians and history writers used 'Saracen,' to mean 'Arab' or 'Muslim,' or both, according to context (p. 8). Other words such as 'Moor,' 'blackman,' 'blackmoor,' 'Negroe,' 'Aethiopian', (or even 'Turk') were used interchangeably in the Medieval era in spite of the fact that the English became aware of the distinctions between different types of blacks (Tokson, 1982, p. 2).

The literary contact engendered a dramatic confrontation in the Crusades literature. The Crusades diffracted image of the Arab world perpetuates some of the old polemical bias. Nonetheless it indicates a slender departure from the Medieval prejudiced outlook on Islam and Muslims. A significant literary groundwork for studying the image of Arabs is embodied in the epic songs of

Chanson de Geste, the oral poetry of Medieval France. These heroic epics were often meant for entertaining the European community. They are found in twelfth century manuscripts. These works proved to be a lasting influence on European literature including English literature.

In the poem The Song of Roland, the Arab is defined as anti-Occident. Arabs of Spain do not have any value. From the storyline in The Song, the Arabs are pagans and believe in idols. The first few lines of the poem depict the Arabian King of Spain, Marsilia. He is shown to be a devout to his gods, a portrayal encouraging the inference that Arabs and Muslims worship Greek divinities and Muhammad. The Arabian King worships Apollo and 'Mahound'. When the King feels that his monarch is going to fall, he starts to seek every deity for help. Saracen or Arab soldiers worship a trinity of gods, named Apollin, Tervagant and Mahomet, whom these pagans beg to intercede for them in battle, much as the Christians do with respect to their God, Christ:

Before them carried their dragon

And the standard of Tervagant and Mohammed

And an image of Apollo, the felon. (v. 3266-3268).

The frontier between France and Arabic Spain was fraught with tension. The battle memorialized in The Song of Roland can be read as a new contest between God and Lucifer: 'At the one stroke the heathen upon the ground did roll\And in that hour Satan hath carried off his soul' (xcvi-ii). Arabs are represented as pagans. They worship Tervagant, Satan and Mohammed. It is a literary portrayal between those who fight for the Christian God and those who fight for Satan. The reference to the false theology of Arabs has aimed to distort and demonize the reputation of Muslim Arabs. In a system constructed of symbols, it was necessary for Medievals to destroy the Islamic signs in order to achieve victory for Christendom. By destroying the pagan idols, Charlemagne destroys the pagans themselves:

And they threw down Tervagant

And threw Mohammed in a ditch

And pigs and dogs bit at them and defecated

On them (v. 2589-2591).

The image of gods is used to establish authority over the Other. In a holy war, if one loses his gods, one is believed to have lost the war. As pointed out by Norman Daniel (1984), 'the Saracen religion in the Songs relates to facts about Islam in the same way as a distorting mirror twists a real object into an unrecognizable travesty' (p. 4). Moreover, C. Meredith Jones (1924) finds out that the conventional Arabs of the Songs of Geste is awful; they are shown as pagans and their practices such as the segregation of women, polygamy, harems, divorce, and sexual promiscuity (p.225). This negative attitude also appears in Medieval drama.

The dramatis personae of the Medieval drama include Arab characters. The earlier Middle English play Mary Magdalene of the Digby Mysteries $\left(15^{\text {th }}\right.$ c.) is a complete and elaborate service held in honour of 'Mahound,' Prophet Muhammad. The lack of accurate knowledge about Islam appears in the dramatists' attempts to represent some forms of Muslim religious rituals. In the temple (mosque), the king of Marcylle proposes to sacrifice his idols to the great one 'Mahound', and during the service, all characters kneel to 'Sentt Mahownde' (Smith, 1977, p.2). The king of Marcylle bids the image of 'Mahound' to speak, but it remains voiceless. In the play Muslims and Christians fight each other. Some Muslims are killed and others adopt Christianity. Magdalene in Mary Magdalene shows the Arab king of Marcylle converting to Christianity. The king finally demolishes his mosque and swears to build Christian churches and to help his people embrace Christianity. He wholly announces his devotion to Christ (Smith, 1977, p. xiii). This prejudice arises out of Crusade propaganda, since the Digby Mysteries stirs up war passion against Muslims.

This image is definitely an attempt to distort the reputation of Arabs, Muslims, and Islam. On the other hand, the name of Herod was discreditably attached with the greatness and blessing of the Arabian Prophet, Muhammad. Herod prays on his death-bed in line with the Christian religious practice. The name of Christ is ridiculously substituted by that of Muhammad: 'My lord Mahound, I pray thee with her enter' (Aljubouri, 1972, p.174). In the Townley Mystery Plays, Herod the Great, Herod starts with the name of the Arabian Prophet Muhammad: 'Moste mighty Mahowne' as a holy pagan deity. In the play, the First Soldier reports that 'Herode, the hend, $\backslash$ king by grace of Mahowne' (9-10). This tendency may best be seen in the treatment of pre-Islamic villains such as Herod, Pilate, the

${ }^{3}$ Saracen. (2011). In Encyclopædia Britannica. Retrieved from http://www.britannica.com/EBchecked/topic/523863/Saracen 
Pharaohs and a variety of pagan kings and queens as Arabs or Muslims. The image of Prophet Muhammad is represented on the British stage as an idol. This was a literary tradition. For instance, the play Mary Magdalene depicts a Muslim sultan offering Islamic rituals and prayers to a brazen head of Prophet Muhammad (Smith, 1977, p.2). The name of Muhammad appears in numerous dramatic scenes in The Play of Wyt and Science, The Play of the Holy Sacrament, The Townely Plays, and The York Mysteries.

John Lydgate's Fall of Princes (c. 1440) stands out as possibly the first English literary piece with baseless accounts of the Prophet Muhammad. It re-echoes some of the polemical offenses on the Prophet's character. In the story Off Machomet the fals prophete and how he beyng dronke was deuoured among swyn, Lydgate describes him as a magician of low birth who was guilty of leading Muslims astray. He speaks of his mother as a Jew since she grew up in a village near the Medina, called Al-Abwa. Lydgate filled his poem with blasphemous depictions of the Prophet Muhammad. Likewise, William Langland (c.1330-c.1386) also seems to have been swayed by the same prejudices in portraying the Prophet (peace and blessings be on him) in Piers Plowman (1362) as a Christian impostor Bishop abusing the power of the Holy Ghost. The second coming in the vision of Piers Plowman is preceded by a time deformed by 'Mahomet' (Oueijan, 1996, p.13). This name of the Prophet 'Mahomet' is also used in the Middle Ages onwards as a generic word for a false god.

\section{A. Image of Arab Scientists}

The Arab civilization played a great role in the development of the modern world. In the process, the Arab culture progressed extremely well during the half millennium from about 750 to 1258. The Arabs appear to have cultivated, with equal success, the instructions and the practice of medical science. They applied themselves to the study of the ancients with extraordinary attentiveness. They had mastered and made their own from whatever was known to the Greeks. Their advances in the newly-discovered science of chemistry soon enabled them to distance their preceptors. For instance, in The Canterbury Tales: General Prologue, the Doctor of medicine refers to historical world founders of medicine including Averroes [(Abu Al-Walid Ibn Rushd (1126-1198)], Avicenna [Ibn Sina (980-1037)], Haly [Ali Ibn Abbas (d.994)], and Razi [Abu Baker al-Razi (850-924)]. They are famous Arab physicians and philosophers of the twelfth century. Avycen, known as Avicenna, wrote the Canon of Medicine in the eleventh century (Ali: p.580):

Wel knew he the olde Esculapius,

And De $\{" y\}$ scorides, and eek Rufus,

Old Ypocras, Haly, and Galyen,

Serapion, Razis, and Avycen,

Averrois, Damascien, and Constantyn,

Bernard, and Gatesden, and Gilbertyn.

Of his diete mesurable was he. (Prologue, 431-437)

The Arab doctors contributed to civilization's intellectual stock. The Islamic sciences were available in England and Europe. Therefore, Geoffrey Chaucer speaks admiringly of several Arab doctors and philosophers such as Argus [alKhwarizmi (780-850)] in 'Book of the Duchess' (435), and Alchabitius [Abd al-Aziz (c.960)] in Astrolabe (1,8,13), and as well Azrachel [al-Zarqali (1029-1087)] in (2,45,2), and Alocen [Ibn al-Haytham (965-1039)] in The Squire's Tale (232). Gibbon (1964) reports that 'the age of Arabian learning continued for about five hundred years, till the fall of Bagdad; and was coeval with the darkest and most slothful period in European annals: but, since the sun of science had risen in the West, it should seem that the unit of Oriental studies have languished and declined' (p.44).

The Elizabethan dramatist George Chapman (1559 - 1634) highly appreciated the transmission of knowledge of Greek to Arabians and then to the West. He admires the Arab scholars Averroes, Avicen and Razi (Maid Lady, 3.3.19) for their contribution to human knowledge. In Sir Walter Scott's The Talisman (1825), the Arabian physician belongs to an Arabian royal family. The Arabian physician successfully cured King Richard of his illness. King Richard appreciated the doctor and describes him as being a descendant of 'nobles of Araby' (p. 350). There were many ways through which the Western writers came into contact with the Arab World. Samuel Chew comments that the influx of literary themes and subjects of fantastic Arabian tales were brought from Palestine during the Crusades; the Western writers "had their part in filling the popular imagination with [positive] dreams and fantasies of the East" (Chew, 1974, pp. 6-7). These Arabian dreams and fantasies, besides the stories, were brought home by Western pilgrims, scholars and travellers.

\section{B. Image of the Arab Kings and Women on the Elizabethan Stage}

The Arabian images in Elizabethan literature are interesting. The late sixteenth century witnessed a flowering of emblematic literature which makes use of earlier Oriental trends with Arabian figures and costume. John Russell Brown believes that a high and costly costume was required to represent these royal characters (Oueijan, 1996, p. 46). Arab characters appearing on Elizabethan London stage were soldiers, maids, sailors, chiefs, princes, princesses, kings and queens. Thomas Newton's book A Notable History of Saracens (1575) was a great source of information to Elizabethan media. Arabian masks as well as Moorish masks were used in 1560. Most of these shows in general represented different countries in the Arab World. In looking at the overall Elizabethan portrait of the Arabs, some Elizabethan writers devoted affection to Arabs. Elizabethan playwrights had a real affinity for Arabs. Arab Kings' appearance with Oriental costume was attractive. They were presented on London stage as leisured, bright and fashionable such as 
Rhesus, King of Arabia, in George Chapman's The Blind Beggar of Alexandra (1596) and Marlowe's Tamburlaine the Great (1587), Crocon, king of Arabia, in Greene's Alphonsus (1590), Almanzor Caliph of Arabia and his general Tarifa, the conqueror of Spain in Revenge for Honour, (1603), the Soldan of Baghdad in Dekker's Old Fortunates (1647), and the Tunisian Prince Mustapha and Princess Donusa in Massinger's Renegado (1624).

Rhesus, King of Arabia in Marlowe's Tamburlaine appears as disappointed and weak. The King's character carries a pre-Islamic name and acts with a secular conduct to Zenocrate. He loves Zenocrate but before marrying her he is murdered by Tamburlaine. The scene is an image of darkness. The scene of the body of the King of Arabia, Alcidamus, lying on the stage is heartbreaking. Rhesus, the King of Arabia, is depicted as a hapless king in Chapman's The Beggar of Alexandria. Naji B. Oueijan's (1996) comment is worth-considering: "Marlowe presented to his Elizabethan audience a picture of the East they desired to see, an Orient filled with treachery, cruelty and false doctrine, an Orient that was destroyed by its own rulers..." (p. 19).

George Peele's famous historical Elizabethan Oriental play The Battle of Alcazar is perhaps written no later than 1591. This play tells of the legend of the battle of Alcácer Quibir in 1578. Muly Mahamet is a descendent of the true Arabian Muly Sharif (1.1.50). Mahamet is labeled with distorted images by his uncle, Abdelmelec, as "the proud usurper", (Act I, i, 77) "tyrant traitor", (Act I, i, 129) "traitor and bloodie tyrant both at once" (Act I, i, 159) and "this Negro moore" (Act II, ii, 902). His younger uncle, Muly Mahamet Seth, took him to be "this traitor tyrant” (Act I, i, 201) and "the traitous Moor" (Act V, i, 1530). Muly Mahamet, on his turn, spoke of his uncle, Abdelmelec, as "the traitor helplesse" (Act IV, ii, 1204), "barbarous Moore" (Act IV, ii, 1236) and "traitor king' (Act IV, ii, 1243). The main historical source for the play is John Polemom's book The Second Part of the Book of Battles, Fought in Our Age (1587). The Arabian King Mulai Mohammed is in full luxury and extravagance. He is portraed as a Machiavellian tyrant. His description is launched in the first lines of the play: '... this tyrant king; $\backslash$ Of whom we treat, sprung from the Arabian Moor, $\backslash$ Black in his look, and bloody in his deeds' (I.i.14-17). Indeed, in The Battle of Alcazar, Muly Mahamet and his uncle are cruel and inhuman.

The portrayal of the Arab women in The Songs of Geste and The Song of Roland is rooted in and builds upon the traditional description of Oriental women. C. Meredith Jones (1924) points out that the image of Muslim woman is in the context of sexuality with Christian knights (p.219). The Arab woman is tagged with pejorative terms like 'whore,' which was often used by Elizabethans to describe Oriental dames. In Peele's The Whore of Babylon, Arabian Iraqi women are identified as whores. In Philip Massinger's Renegado (1624), Paulina says, 'I will turn Turk [means Muslim];' Gazet answers, 'Most of your tribe do when they begin in whore' (4, 2, 43). Massinger engenders in the mind of the Elizabethan audience a misconception about the Islamic sexual repression. Massinger tries to draw a contrast between 'Christian purity' and 'Muslim sensuality.' Donusa, a Tunisian princess, falls in love at first sight with an Englishman, called Vitelli. She tenders her body to him, for 'her religion allows all pleasure'. Driven by her promiscuity, she calls Vitelli to her private room and asks him keenly for the second entertainment the next day (Kidwai, 1995, p.145).

Women in Chapman's plays are accused of adultery, and consequently they suffer. For example, in Revenge for Honour, Caropia falls dreadfully ill when she is falsely accused by her one-sided lover, Abrahen. She is killed by Abrahen. It seems that Chapman's Caropia is judged by her sexuality even when she remains faithful to her husband and husbands-to-be. Some feminists believe that this demonstrates a male insecurity about female sexuality. The term 'honour' or 'prostitute spirit' is considered quaint or outdated by Chapman. The story dubs interest in Othello: The Moor of Venice (1603). Othello's reference to Arabia depicts that he is an Arab and draws attention to extreme jealousy harboured by Arabs. Many threads of the plot of jealousy have equivalents in Cupid's Revenge (1612). To this extent of jealousy may be included even closer jealousy parallels between Revenge for Honour and Glapthorne's Albertus Wallenstein (1639), and Carlell's Osmond, the Great Turk (c. 1639).

The overstated outlook that a woman who converts to Islam becomes a prostitute is a product of evangelic misinformation. The image is purposely formulated for the English woman who desires to embrace Islam. Islamic teachings might turn her into a whore. As a punishment, the Christian girls married to Muslim, would be fundamentally disconnected from their parents. History books like Notable's History of the Saracens state that Arabs conquered states all over the world, and a number of female captives were taken into a legal concubinage (Kidwai, 1995, p.89). Therefore, nations were offended; but most people converted to Islam. Furthermore, in Twelfth Night, Shakespeare tells about an Englishman, who has lived in Baghdad, and got married to a 'fair' Arab woman. She was fair and righteous that caught the fancy of English ladies to be like her and live saintly (2.3.80-84). It is no coincidence that Shakespeare refers to the righteous Arab woman in relation to his admiration.

In Marlowe's Tamburlaine, the noble Olympia, wife of the Captain of Basra, is a strong Arab lady. She is represented as a brave and honest woman. Olympia is victimized by Tamburlaine and Theridamas. In a distress scene, she witnesses the murder of her husband by Tamburlaine. However, she has knifed her son who could not bear to see the shame of defeat and wants to meet his father. She claims that Captain of Basra, is 'in heaven' (Part II, 3.4.30). She felt sorry for 'this sin' and pleaded to God and 'Mahomet' for forgiveness. She took the corpse of her son to burn it along with his father, as a protest against the oppression of Tamburlaine. Shortly, Theridamas murdered her since she rejected his bid to marry him. Olympia represents the Arabian Phoenix bird in her killing her son and life. 
The image of the Arabian woman wearing black masks with little clasps prettily ordered appears in Thomas Moore's narrative poem Lalla Rookh (1817). Arab woman covers most of her face except for a slit or a hole for one or the two eyes:

And veiled by such a mask as shades

The features of young Arab maids,

A mask that leaves but one eye free,

To do its best in witchery. (The Light of the Haram, 319-322)

Thomas Moore wants to introduce the Arab woman habit in using the veil on body and face. The image of Islamic veil is alien in the secular Western societies.

\section{Portrayal of Arabs in Arabian Nights}

The first English translation of the Arabian Nights is published in 1715 for Andrew Bell. This work popularized the image of Arabs. The impact of this English translation of Arabian Nights was abundant. The English literary works of the eighteenth and nineteenth centuries had been revival themes from the Nights. Sir Richard Burton's (2001) Arabian Nights' Entertainments is stylistically plain and literal translation with an introduction and explanatory notes on the manners and customs of Arabs. It has been popular in England. Meester speaks admirably about this translation saying:

[These stories] furnished on our languages with number of expressions and images, they have imprinted on our minds many scenes of Oriental life. This last point is among the greatest merits of the Thousand and One Nights: they give such a faithful picture of the Orient, its life and customs, that many people who afterwards happen to visit those countries on oriental conditions and described in the Nights' (p.13).

The Arabs are portrayed as inhabitants of a magical and mysterious world, full of jinns, flying horses, and supernatural birds and replete with exotic scenes of harems, princes, slaves, eunuchs, along with wonderful stories like those of Ali Baba and Sindbad.

The Arabian images have been part of the panoramic colours of the English Victorian literature. The appearance of the Arabian Nights in English made the Arabic themes very popular. Since very early times, the East and its literature has been a source from which the West has freely borrowed. William Thomas Beckford's (1760-1844) Vathek, an Arabian Tale or The History of the Caliph Vathek (1786) is a story of an Abbasid Caliph. The title character is inspired by Al-Wathiq ibn Mutasim (842-847) who had a great thirst for knowledge and who was a great patron to scholars and artists. During his reign, a number of revolts broke out. He took an active role in quelling them. In Vathek, the themes of lust and violence are central to the story. The text, therefore, hardens stereotype, and provides nothing new in English literature about Arabia, but follows the typical Orientalist pattern. Indeed, these texts - in creating a barbaric Arab out of the East - continue a tradition which dates back to the Medieval Age of Chaucer and Gower. Vathek carries forward the conventions of the Arabian Gothic. The violent and autocratic ruler in the form of the Caliph Vathek works only to satisfy his wants.

The Arabian Caliph Vathek lives in extremely excessive luxury; when he inherits the palace, he adds "five wings, or rather other palaces, which he destined for the gratification of each of the senses" (Vathek, 2). To please his physical sense, the palaces of The Eternal or Unsatiated Banquet is shaped, where, "the most delicious wines and the choicest cordials flowed forth from a hundred fountains that were never exhausted"(Vathek, 2)., for his sense of sight there is "The Delight of the Eyes, or The Support of Memory" in which, "Rarities, collected from every corner of the earth were there found in such profusion as to dazzle and confound". The final fifth palace is to satisfy his sense of sexual touch in harem. This scene is frequented by troops of Houris, young beautiful females. The Arabian Caliph is lustful. He never misses to receive embraces and enjoys hours of the company of young females (Vathek, 29-30).

Likewise, George Gordon Byron's (1788-1824) Giaour (1813) shows the Islamic image of evil, Eblis or Satan: 'the blood of fifty children ... [taken] from the most beautiful sons of thy viziers and great men' (Giaour, 42). Byron designed the story with three narrators giving their individual point of view about the series of events. The main story is of Leila, a member of her master Hassan's harem, who loves the Giaour and is killed by being drowned in the sea by Syed Hassan, an Arab dictator. In revenge, the Giaour kills Syed Hassan and then enters a monastery due to his remorse. The design of the story allows for contrast in Christian and Muslim perceptions of love, sex, death and the afterlife.

Like Byron, Robert Southey (1774-1843) is fascinated by Arabian characters. In his poems 'Thalaba, the Destroyer,' the young Arab, Thalaba, demolishes the kingdom of the magicians, Domdaniel, under the sea. With the support of a magical ring, Thalaba, the hero, overcomes his supernatural enemies and destroys the sorcerers and their rich kingdom. Thalaba's story contains elements from the Arabian Nights such as the magicians, sorcerers, nags, and a flying horse. Though Southey utilised Arabian Nights' elements, he relates Islamic references to depict the image of Arabian characters. Southey, who knew very well George Sale's English translation of the Qur'an, believed that Islam is an extension of Christianity and that Muhammad is an evangelic prophet. Southey's vision refers to Islamic theology that "in Thalaba the beliefs and customs of the Islamic Orient are a survival of the ancient life and faith of the Bible"; Southey goes on to say that "Islam is used as a model for the regeneration of European civilization," and that Southey considered that "Islam in itself could play an effective part in the understanding of man and human consciousness" (Thalaba, 124, 105 - 106). Unfortunately, however, a few years after the publication of Thalaba, Southey, who did not study Islam at first hand, yields to popular misconceptions when he presents contradicting views of Islam in his prose work Chronicle of the Cid (1808). Southey's reference to Islam here is an entirely unfavourable approach to depict an 
image of an Arab. Some writers refer to Arabia because they were familiar with part of the Islamic knowledge through travels which invigorated the interest in Orientalism.

\section{Image of the Bedouin Arabs}

The English fascination for the Arabian Desert and its citizens was developed in the notion of the English writers who possessed an intuitive understanding of Arabs because of the travel publications. Wordsworth splendidly dreamt of the desert and the Arab Bedouin. In Book V of The Prelude, Arabia fills Wordsworth with a sense of wonder and marvel. While reading a book on a beach, he dreams and discovers himself in a dry sea, a desert, and takes a look at a Bedouin Arab who holds a stone and a shell in his hands. Besides, the idea that the desert of Arabia represented emotion and freedom, primitive yet passionate and powerful, attracted the Romanticists. This tendency to establish and romanticize was exotic by itself. The dream of the Bedouin Arab in the Prelude (V, 86-102) stands for a fascination of the literary Orientalism in the Romantic Age. More significantly, the Arab in The Prelude responds to the dreamer's questions, implying the opportunity for opening channels of communication between the West and the Arab World. Wordsworth is, perchance, the primary author to award this equivalent status to an Arab who is no more traditionally cast in the position of a combatant or an enemy.

Unlike Pope who in The Dunciad described Arabs as an ill-mannered people against learning and charged them burning libraries, Wordsworth acknowledges the great Arabian scholarly institutions and contributions to world knowledge. The Arab correspondingly comes into view with books of science and poetry; so doing, Wordsworth admits the Arab perpetuation and communication of knowledge which helped recover Greek thoughts. Far from the conservative "Noble Savage", Wordsworth's Arab stands out as a culture-hero. The stone is "Euclid's Element," and the poet recognizes it to be a volume of "geometric truth"; the shell is a book of poetry which prophesies the demolition of the world by a flood. This image "reaches the very 'ne plus ultra' of sublimity" (526). William Wordsworth advocated it for being "useful in calling forth intellectual power. ${ }^{4}$

Some successful English travels in the nineteenth century brought information about the Arabs. English travelers provided a perfect physical description of people of the Arab World. Some characteristics of the Arabian folkways and prototypes of life were more than those in earlier reports. The most popular collection was William Alger's The Poetry of the Orient, first published in 1862. Alger gives a free poetic rein to his picture of the Arab personality which he says the poetry conjures up:

Visions of tawny brows, flowing beards, soft eyes, picturesque turbans, pawing chargers, patient dromedaries... It is the land of the date tree and the fountain, the ostrich and giraffe, the tent and caravan.... Hospitality waves her torch through the night to win the wanderer to be a guest. Reeking vengeance, with bloodshot eyes and dripping blade, dashes by on a stallion shod with fire (p.50).

The twentieth century literature produces modern Western Oriental material with reference to Islamic theology. For instance, Robert Hichen's The Garden of Allah (1904), is a paradoxical story about the tropical climate of Algeria. The epic novel tells of the adventure of a young English woman alone in the Sahara Desert. The story continues to enchant and manoeuvre for a paradoxical Garden of Allah in the dark mystery and rich cultural environment of Algeria which is hot humid climate, noisy cities, and exotic evenings. The Garden of Allah refers to the Arabs' submission to the will of God: 'The Arabs, at any rate, do not buzz against their Creator, like midges raging at the sun in whose beams they are dancing" (p.159). The theme of the Arabian wildlife in the desert is interesting. W.B. Yeats' A Vision (1925) gives an account of Arabic interests in the Arabian horse and the Desert. Besides, the Arabian romance of Yeats' 'Kusta ben Luka' evokes the Orientalism of Lord Dunsany's play The Tents of the Arabs (1920) and Elroy Flecker's Hassan: The Story of Hassan of Baghdad and How He Came to Make the Golden Journey to Samarkand (1922). These Oriental literary materials are influenced by the Arabian Nights. In relation to the excitement of the Oriental literary material, G.M. Trevelyan in his English Social History (1944) points out that 'wicked [Muslim] kings who wore a turban' are represented in Arabian contemporary costume symbolically to indicate their status in England theatre (p.89).

The Medieval image of Saracen Arabs in Europe has been recycled in the twentieth century. Bedouin Saracens appear in the name of real characters of early Islamic Arabia. The images of Prophet Muhammad, Caliph Abu Baker, Caliph Omer, etc are recycled to crystallize the trend of Islamophobia in Europe. The growth of Islamophobia makes some literary writers to depict Islam as a threat to Europe. For instance, Salman Rushdie's The Satanic Verses (1988) is blatantly and unapologetically offensive. Rushdie devastatingly targets Islamic symbols in representing the Prophet Muhammad and his companions in a medieval misinformation. The Satanic Verses has a religious theme to falsify the holy Qur'an and its Prophet. The character of the Prophet Muhammad is represented as a charlatan and a heathen idol worshipped by the Arabs. It is a duplication of the medieval attitudes in assaulting Prophet Muhammad and in 'exposing' Islam. Rushdie uses the medieval names of 'Mahound,' 'Mahoun,' 'Mahun,' and 'Mahomet,' which were Christian synonymous with demon, devil, or idol. The name was invented by the authors of Christian play series and romances of twelfth century England (Armstrong, 1993, p. 42). For many Englishmen, the Arabian theme is still understood in terms of the Christian polemic history. Arabs and Muslims are heathen and violent infidels though they share much from both Jewish and Christian contexts. This inaccurate and prejudicial outlook is part of a profound ignorance in the West about the Orient of Islam.

${ }^{4}$ Letter of 16 December 1845 to S. Tremenhere in Letters, the Later Years, ed. E. De Selincourt. Oxford, Clarendon, 1939. III, 1269. 
With the end of the cold war and the rise of radical Islamic factions in the Middle East, the disagreement between Islam and the West has raised. The theory of Samuel Huntingdon in the "Clash of Civilizations" moves up the political spectrum. The anti-Western language of many Muslim militants has pumped up the confrontation which has come to be widely anticipated. At the same time, many issues afflicting the Middle East itself - from the Arab-Israeli conflict and the Gulf War - are widely seen as reflecting the influence of Islam on politics and society of the Orient. In contrary, the Arab critic Edward Said introduces Orientalism as a cross-cultural interaction between the Occident and the Orient. In his book, Islam and the myth of confrontation: Religion and Politics in the Middle East (1995), Fred Halliday, a modern linguist, refutes these interpretations of clash. He considers the source of Islamic threat is an illusion. Halliday calls the Islamophobic, racist, and stereotypical elements are all anti-Muslim demagogues.

\section{THE ARABS OF 9/11}

The image of Arabs has been tarnished by the event of 9/11/2001, despite the efforts of the objective investigation for the East-West relationship which refutes the feeling of incredibility between the East and the West. The event of 9/11 and its aftermath is not between Islam and Christianity. The event is caused by the Jihadist movements and Western politicians for the sake of power. In his authoritative work Orientalism, Edward Said (1979) goes on to assert that the hostile political relationship between the East and the West was from its beginning, a hostile relationship between Islam and Christianity (p.59). In fact, it is not the problem of religions. It is a struggle of power and business. Norman Daniel (1986) points out that in early times the dominant belief of the Muslim Arabs and Mediaeval Christian Europe, was of resemblance rather than difference 'dominated the dogmatic, liturgical and moral bases of the two religions' (p. 13). It was not unusual for a Christian king to have Muslim partners, or for a Muslim to turn to a European king for help, being relatively unconcerned about culture and religion (Daniel, 1986, pp.51, 62).

A new literary trend in Islamic material emerges in the writings of some Western writers. The appearance of religious symbols dominates the titles of some literary works. Paul Torday's Salmon Fishing in the Yemen (2007) is a literary response to the events of 9/11 five or six years later by Torday. The United States of America has been attacked on home soil by a radical Islamists from Arabia. The attack is the outcome of the cultural changes in the Arab World's affairs. Torday's novel is about an enterprise for fishing Salmons in Yemen. This civil project is an unbelievable Western project in Arabia. As a fable, Paul Torday's Salmon Fishing in the Yemen is the offspring of a classic tradition that goes back to Aladdin of Arabian Nights. The luxurious sheikh Zaidi is pro-British. He is fully familiar with the Western lifestyle. He has a dream of a Western project of fishing salmons in Yemen which is considered to be an achievement of a miracle. In fact, the climate of Britain and Yemen is incomparable. There is no similarity to get life for the clod-life-natured fish of salmon in the hot environment of Wadi Aleyn. The theme of Islamic or Arabian terrorism appears in Salomon Fishing in the Yemen. The novel is his first attempt to write fiction after the emergence of "political Islam" of 9/11 where terrorists cruelly attacked the Twin Towers in the United States of America in 2001. The war against the Taliban movement in Afghanistan and the war in Iraq are synchronized with the events in the novel. The project is perceived by the local Arabs of Yemen as a political movement to westernise the country. The Al-Qaida cell in Yemen violates the Western project and calls it a war on Islam. The terrorists perceive the establishment of the project in the context of a crusade.

Fiction is the preeminent narrative. Some new fiction writings include a fiction of Arab Islamic symbols. Historical Arab religious personalities are represented in English literature as heroes for European readers. Sherry Jones's The Jewel of Medina (2008) is a platform for the propositions of the political development after September $11^{\text {th }}$. The novel is a fictionalized version of the historical life of Aisha bint Abi Bakr, one of the wives of Prophet Muhammad, and the person who reportedly accompanied the Prophet. Aisha was born in the seventh century Arabia, and often referred to as Prophet Muhammad's favourite wife, from her engagement at the age of six until the prophet's death. Sherry Jones endeavours 'bring the love story of Aishah and Prophet Muhammad to the West. Romance novel about a prophet of Allah is wrapped in the face of innocence. From beginning to end, the hinge is sex, and these imagined encounters and implication never cease. For Muslims, the novel is filled with blasphemous depictions of the Prophet Muhammad and his faithful wife. In her new other novel, The Sword of Medina (2011) Sherry Jones writes a sequel to The Jewel of Medina. It deals with Islamic history through the eyes of Prophet Muhammad's youngest wife, A'isha. For some she is an inspiration, for others she is a curse because she caused the split between Shi'a and Sunni Muslims. In her novels, Jones offers her interpretation of A'isha's childhood, her secret love, her marriage, and her conflict with Muhammad's nephew Ali. Above all, Jones narrates Islamic history as a love story.

To sum up, the West views Arabs as ministers of terrorism. Western intelligent agencies depict some terrorists as monsters who try to destroy the West. The threat of Islam has been portrayed as imminent. Some of the Western elite have warned their states of a clash of civilization with the Orient. In reality, the Islamic states have cooperated to defuse the threat of terrorism. The portrait of Arabs in English literature can be improved with more Oriental studies in Europe. The spread of the Arabic culture can bring a better understanding of Arabs. Furthermore, Middle Eastern films can be distributed widely and can help spread Arabic culture in the West.

\section{CONCLUSION}


Arabs are misunderstood in the West. The Englishmen understand the secular Arabs from the fables of the Arabian Nights, and understand the Islamist Arabs from the biography stock of early Muslims and Islam. The struggle between the West and the Arabs is between the 'good' and the 'evil,' which has been expressed in literary works. Some English writers retain polemical distrust in the Arabs. The moral and social misbehaviour in the conduct of Arab characters underscores their human weakness. They have been largely portrayed as unsuccessful people, committed to repeated errors. Edward Said (1979) states, what 'we know of the Arab world is coloured by distorted lenses of scholars who have historically defined this area as alien, corrupt, dangerous, and mysterious"(p.63). Encountering the Islamic Orient has been a significant element for the self-image of the West, and it has manufactured identities that have employed discursive constituents, scoping from corrupt European modernity to cultural, racial and moral superiority. As far as religion is concerned it seems to be natural for some English Arabicists to be highly critical of Islam and Arabs in order to substantiate the colonial ideology of the West and its applications in the Middle East. David Roberts, the painter of idealised landscapes of classical ruins, expresses his dissatisfaction as dislike of Arabs:

Splendid cities, one teeming with a busy population and embellished with temples and worlds, now deserted and lonely, or reduced by mismanagement and the barbarism of the Muslim creed to a state as savage as the wild animals by which they are surrounded. Often have I gazed on them till my heart actually sickened within me (Bernard, 1912, pp. 104-5).

Authentic knowledge can draw the Arabian image in the portrait of the world civilization. The literary Orientalism can be represented in the scope and range of the media. Some English writers have an evocative and elusive talent and have possibly created modern Arabian images, which could arguably represent an original style. The Arab characters are, on the whole, reasonable. They are thoughtfully a product of the cross-cultural sympathy and harmony. Arab kings, queens, commanders, knights, soldiers and messengers, are stylized in Arabian costume and rituals, but nevertheless, they are like Englishmen, as they are familiar with the English lifestyle. On the other hand, some Arab Characters are depicted with various types of rhetoric that ranges from lyrical to humorous, eccentric, dramatic, cutting or intricate in style, and using creative loaded tropes. Elaborate characters and literary devices such as tales, letters or twofold viewpoints express dissonance and give some of these narratives a sort of 'baroque' flavour. The English writers have formed new literary tools to address postcolonial Muslim identity. The characterization expresses the fluidity of the contemporary Muslim identity portrayed in the novels, its dynamic evolving state, and thus the roots of its hybridity. To the rationale of humiliation, these writers offer artistic evasiveness of the characters. The differences between the Europeans and the Arabs can be minimized to the point of erasure when the act of producing humanistic literature promotes understanding between nations.

\section{REFERENCES}

[1] Ali, Syed Ameer.(1961). The Short History of Saracens (London, Macmillan).

[2] Aljubouri, Dhia A. H. (1972). 'The Medieval Idea of the Saracens, as illustrated in English Literature, Spectacle and Sport', Unpublished Ph.D. Thesis (Leicester, University of Leicester).

[3] Alger, William. (1865). The Poetry of the Orient (New York, Roberts Brothers)

[4] Armstrong, Karen. (1993). Muhammad: A Biography of the Prophet, (New York, Harper San Francisco).

[5] Ballantine, James. (1986). The Life of David Roberts, R.A. (Compiled from his journals and other sources) (Edinburgh, A\&C. Black).

[6] Bernard and Ellen, M. Whishaw. (1912). Arabic Spain: Her History and Arts (London, Smith Elder).

[7] Beaumont, F. and Fletcher, J. (1905). The Works of Francis Beaumont and John Fletcher, ed. Arnold Glover \& A.R. Waller (Cambridge, University Press).

[8] Bennet, J.W. and et al. (1959). Studies in The English Renaissance Drama (New York, New York Press).

[9] Brock, Heyward. (1983). A Ben Jonson Companion (Indiana, Indiana University Press).

[10] Burton, Richard F. (2001). "Preface," in The Arabian Nights, Tales from A Thousand and One Nights, translated by Richard F. Burton, (New York, Modern Library).

[11] Chew, Samuel C. (1974). The Crescent and The Rose: Islam and England during the Renaissance (New York, Octagon Books).

[12] Daniel, Norman. (1984). Heroes and Saracens: A Reinterpretation of the 'Chanson de Geste.' (Edinburgh, Edinburgh University Press).

[13] Daniel, Norman. (1986). The Arabs and Mediaeval Europe (London, Longman)

[14] Florian, M. (1857). History of The Moors Of Spain (New York, Harper).

[15] Forster, Charles. (1829). Mahomedanism Unveiled (London, Duncan).

[16] Gibbon, George (1964). Decline and Fall, vol. (London, Macmillan).

[17] Hitti, Philip. (1964). History of The Arabs, (London, Macmillan).

[18] Halliday, F. (1995). Islam and the myth of confrontation. Religion and politics in the Middle East. (New York, I.B. Tauris Publishers).

[19] Jones, C. Meredith. (1924). "The convetional Saracens of The Songs of Geste," Speculum, 17.

[20] Jones, Sherry. (2008). The Jewel of Medina (New York, Random House,).

[21] Jones, Sherry. (2010). The Sword of Medina (New York, Random House).

[22] Jonson, Ben. (1939). The Complete Works of Ben Jonson, ed. H. Nerford et al. (Oxford, Clarendon).

[23] Kidwai, A.R. (1995). Orientalism in Lord Byron's 'Turkish Tales' (Lewiston, Mellen University Press).

[24] Kidwai, A.R. (1997). The Crescent and The Cross: Image of the Orient in English Literature Up to 1832 (Aligarh, Aligarh Muslim University Press). 
[25] Mack, Robert L. (ed.) (1995) 'Introduction', Arabian Nights' Entertainments (Oxford, Clarendon).

[26] Mahood, M.M. (1999). Marlowe's Heroes, in Elizabethan Drama: Modern Essays in Criticism, ed. R.J. Kaufmann, (London, Duncan).

[27] Manely, Marry. (1999). Almyna or The Arabian Vow (London, Macmillan).

[28] Mansoor, M. (1944). The Story of Irish Orientalism (London, Longman, Green and Co., Ltd.).

[29] Marlowe, Christopher. The Works Christopher Marlowe, ed. F. Bowers, Vol. I, The Jew of Malta, (London, Longman)

[30] Meester, Marie E. De. (1914). Oriental Influences in the English Literature of the Nineteenth Century (Amsterdam, xxxx).

[31] Oueijan, Naji B. (1996). The Progress of an Image: The East in English Literature. (New York, Peter Lang).

[32] Parrott, Thomas Marc.(ed.) (1910). Tragedies of George Chapman (New York, Macmillan)

[33] Said, Edward. (1979). Orientalism (London, Vintage).

[34] Shakespeare, William. Henry VIII, ed. R. R. Foakes (1968), Arden Edition (London, Methuen).

[35] Shakespeare, William. The Tempest, ed. Frank Kermode (1963), Arden Edition, (London, Methuen).

[36] Shakespeare, William. Twelfth Night, ed. A.W. Verity (1994) (Delh, Surjeet Publications).

[37] Smith, Byron Porter. (1977). Islam in English Literature (New York, Caravan Books).

[38] Tidrick, Kathryn. (1989). Heart-beguiling Araby, (London, xxxx).

[39] Trevelyan, G.M. (1990). English Social History (New Delhi: Orient Longman).

[40] Tokson, Elliot. (1982). The Popular Image of the Black Man in English Drama, 1550-1688 (Boston, Mass., G. K. Hall).

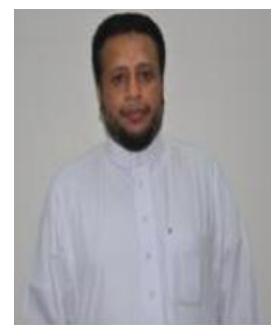

Fahd Mohammed Taleb Saeed Al-Olaqi was born in Aden, Yemen, on March $28^{\text {th }}, 1972$. He did his primary and high school Education, in Aden. He completed his B.A. in English in the Department of English, University of Sana'a, Yemen. He has done his M.A. education (1999-2001) in English in Central Institute of English and Foreign Languages, Hyderabad, India. Dr. Fahd Al-Olaqi has obtained his Ph.D. in English from Aligarah Muslim University in 2004.

Dr Fahd was selected two times by Insights Journal to review articles with Islamic material in English literature.

After three years of service as a teacher and an Assistant Professor of English, Department of English, Faculty of Education - Shabwah, University of Aden, Yemen. He taught English as a part-timer in different institutions in Shabwah and Aden. He has moved in 2007 to King Abdulaziz University, Faculty of Science \& Arts - Khulais in Saudi Arabia. Dr. Al-Olaqi is now an assistant professor of English in the Department of English \& Translation. He works on issues of race, travels and religion Orientalism in Elizabethan English literature as well as on projects about the biography of Prophet Muhammad and the Holy Quran in the Western writings.

Dr. Fahd Al-Olaqi An article entitled 'Image of Aden in English Travellers' Literature' published in Al-Tawasul Magazine Vol. 11, issue 9, 2009, University of Aden, Yemen. An article entitled "Image of the Messenger Muhammad (PBUH) in English Literature", Insights Journal, Vol 3, issue 2, 2010, Islamic University of Pakistan. A research article under refereeing "The English Koranic Images in Some Literary Writings" The Elizabethan Images of the Quran; A research article published "MARLOWE'S TAMBURLAINE (1587) AND ISLAMIC THEOLOGY" in TRAMES, 2012, 16(66/61), 2, 177-201. ISI Ranking Journal; Another research paper:"The Influence of the Arabian Nights on English Literature A Selective Study" Accepted to be published in the European Journal of Social Sciences, 2012; and July 2012 Under Reviewing "Soliman the Magnificent in Kyd's Soliman and Perseda". Dr. Fahd has also published a book (ISBN: 978-3-8473-0060-1) entitled ELIZABETHAN ORIENTALISM OF MARLOWE, SHAKESPEARE AND BEN JONSON. For more contact: http://sak.njb.kau.edu.sa, Email: fahdmtm@yahoo.co.uk. 